\title{
SUB SCEPTRUL CREŞTIN AL LUI MIRCEA I BASARAB, PRIMA UNIRE ROMÂNEASCĂ MEDIEVALĂ
}

\author{
Prof. dr. George Coandă
}

\author{
Universitatea „Valahia” din Târgovişte, biblioth@gmail.com
}

\begin{abstract}
In the true historical spirit, it must be mentioned that Mircea Basarab the I (named: the Great; the Elder), whose reign took place between 1386 till 1418, was the founder of the first medieval Romanian Union, proved by his title of ruler, before the Union conducted in 1599 1600 by Michael the Brave. The differences are that Mircea the Elder conceived the first Union on a limited area but reuniting under the scepter of the voivode small fragments from all over the historical Romanian arias from the North Carpathians, Banat, until Dniester and the Black Sea, whether the second Union, of Michael the Brave, gathered all the arias presented, excepting Dobruja. Therefore, is important to acknowledge the first Union in the XIVth and XVth Century conducted by Mircea the Elder.
\end{abstract}

Keywords: Carpathians, Ungrovlahia, Amlas, Fagaras, Severin, Basarabia, Bugeac.

1.

Întreaga istoriografie românească, şi nu că n-ar fi de înţeles, este setată încă pe ideea că, prima Unire a pământurilor locuite de români dintre Carpaţi, Dunăre şi Nistru, s-a realizat din vrerea, geopolitică - aşa cum o vedem noi astăzi -, îţ̦eleaptă şi de un impresionant curaj în împrejurări internaţionale potrivnice, a domnului/voievodului Mihai Viteazul, de os Basarab, la 1599-1600, şi care a dăinuit doar până la 1601. De bună seamă că pe drumul lung spre înfăptuirea Unirii depline de la 1918 a fost, fie şi fulgurant, o uriaşă victorie de etapă care a aşezat acea Românie Mare, avantla-lettre, pe harta politică a Europei, la încrucişarea Evului Mediu cu Renaşterea în cazul românilor. A fost să fie o renaştere a românilor prin ei înşişi din propria cenuşă a trădărilor dinăuntru şi a înjunghierilor din afară (otomane şi habsburgo-maghiare).

Însă, dacă privim geografic-politic cu atenţie acea, da, extraordinară realizare statală mihaidă, observăm că n-a fost să cuprindă în graniţele sale toate orizonturile cardinale ale Vetrei istorice româneşti, şi anume getodacica Seythia Minor (Dobrogea), cucerită de la Țara Românească, în 1417 , de sultanul Mahomed I (1413-1421), nu făcea parte din această geografie. De ce este considerat încă primul unificator al Țărilor Române Mihai Vteazul, răspunsul are, şi este, cum spuneam, de înţeles oarecum, o ambivalentă motivare: a) până la 1599-1600 existenţa a două state în geospaţiul carpato-danubian-nistrean, Ţara Românească, Moldova, şi a unui principat autonom, Transilvania, inclus, prin cucerire, în Regatul Ungariei, apoi în Imperiul Roman de Naţiune Germană (Habsburgic), le-a obturat istoricilor perspectiva unei corecte cercetări, necutezând să depăşească această limitare; b) la începutul secolului XIX, când românii au intrat, la rândul lor, în procesul complex de formare a statelor naţionale moderne, pentru a-şi justifica istoriceşte necesitatea creării propriului lor stat şi-au căutat şi valorificat miturile fudamentale întemeietoare, şi cum beneficiau atunci de o tânără intelectualitate bine instruită în şcolile Occidentului, şi, mai ales, la Paris, modelul francez fiindu-le unul de bun augur, această intelectualitate a găsit miturile respective şi le-a promovat insistent în mentalul colectiv în, 
de pildă, epopeea dacică (Burebista, Decebal), de unde ideea forţă unionistă a Daciei rediviva, sau în cealaltă epopee, medievală, a lui Mihai Viteazul, perceput simbolic ca un restitutor Daciae, autorul acribic şi patetic persuadant fiind paşoptistul Nicolae Bălcescu. Şi asta dintr-o singură pricină: fapta unificatoae a viteazului voievod, rezultat al bătăliilor victoriase împotriva Imperiului Otoman şi a lui Andrei Báthory, cardinalul principe al Transilvaniei, şi Ieremia Movilă, domn al Moldovei, uneltitor al Poloniei lui Sigismund III, care îşi fixase ca obictiv major de politică externă înlăturarea din tron a lui Mihai şi extinderea „sferei de influenţă” până la Dunărea de Jos, fapta, deci, avusese un amplu ecou în epocă. Şi era mult mai bine fixată în amintirea neamului, intrată chiar în folclor, şi datorită distanţei nu prea mari în timp de când avusese loc, doar două veacuri.

Şi, totuşi, înaintea lui Mihai Viteazul a existat o altă epopee unficatoare, la fel de eroică şi legendară, croită cu spada şi sub sceptrul creştin al lui Mircea I Basarab (1386-1418), reţinut de istorie şi cu cele două apelative encomiaste, cel Mare şi cel Bătrân mai ales. Căci, Mircea I a fost animat, în îndelungata sa domnie, de o ardentă conştiinţă de neam. Să luăm aminte la înrudirea sa, prin soră, cu Roman I al Moldovei (1391-1394), şi la actul, şi frăţesc, şi politic, de a-l fi ajutat să urce pe tronul de la Suceava pe nepotul său Alexandru cel Bun (1400-1432). Dar şi de dorinţa, izvorâtă din această conştientizare, de stăpânire, în sens geopolitic şi geostrategic de reunire sub coroana sa - însemn al suveranităţii statale a câtor mai multe pământuri româneşti, urmărind să construiască un stat puternic, capabil să fie pavăză dăinuirii neamului şi stavilă unor tendinţe expansioniste în această parte de Europă (central-sud-estică). În fond, Mircea, ca şi urmaşul dinastic la aproape două veacuri, Mihai Viteazul, a întreprins acţiuni unificatoare şi de apărare în aşa fel încât, în complicata ţesătură geopolitică internaţională de la intersecţia secolelor XIV şi XV, să-şi operaţionalizeze benefic, pro patria, avantajele, în pofida ameninţătorului deficit de securitate care ar fi putut duce la extinţia Ţării Româneşti (Valahia Magna). Or, de la întemeierea acestui stat - a se reţine: prin unire de cnezate şi voievodate sudcarpatice -, faţă de momentul urcări pe tron a lui Mircea, trecuseră abia 86 de ani. Asumâdu-şi temerar riscul, Mircea a reuşit un act istoric care a prezervat statalitatea medievală românească, încă la începutul său, pentru atunci, cât şi pentru viitorime. A ferit de paşalizare spaţiul românesc. Acesta a fost rostul militar (bătăliile de apărare) şi geopolitic-diplomatic (capitulaţiile spre sfârşitul domniei) al „raţiunii de sat” a lui Mircea I.

Putem vorbi, fără nici un dubiu, ţinând seama de acţiunile sale de întărire economică şi militară a Ţării Româneşti, şi de extindere teritorială a acesteia, nu altundeva decât în Vatra istorică a românilor, de prima Unire românească sub sceptrul creştin ortodox al domnitorului/voievodului Mircea I Basarab. Unire, e drept, pe o spaţialitate redusă, dar care a strâns sub sceptrul amintit părţi din toate pământurile româneşi de la nord, sud şi est de Carpaţi. Este de precizat, în spiritul corectitudinii ştiinţifice, că, opera unificatoare debutase cu un secol mai înaintea domniei lui Mircea I Basarab.

$A b$ origine. Țara Românească a fost rezultatul unui proces, şi firesc (etnocentripet unificator), şi de apărare (etnoegidă strategică) a voievodatelor şi cnezatelor valahe dintre Carpaţi şi Dunăre, de la vest şi de la est de Olt, statul astfel ctitorit fiind cunoscut mai ales în cronicile bizantine şi în cancelariile medievale europene cu denumirea „Ungrovlahia”. Adică, Valahia vecină Regatului Ungar, regat cu evidente tendinţe acaparatoare de teritorii străine, tendinţe care au determinat şi grăbit apariţia Ţării Româneşti. Apariţie, care, după Nicolae Iorga, a precedat domnia lui Basarab I, ea producându-se parţial sub 
tatăl său Tihomir/Tocomerius (1290-1310). Fiul, de la 1310, când a urcat pe tron, nu a făcut altceva decât să fie ,un continuator, iar la urmă, şi un liberator", Basarab I luând "şi el, dincolo de moştenirea sa, pământuri regale" [1].

De fapt, „pământuri regale" aduse ca „liberator" şi „continuator” de Basarab I sub coroana sa unificatoare, pământuri locuite de români la est de Olt, până atunci aflate sub dominaţia regalităţii maghiare. Din acel moment s-a conturat ceea ce cancelaria ungurească a numit „Terra Bazarab”, iar autohtonii „Ţara Românească”. Afirmarea şi consolidarea sa, a ,primei libertăţi româneşti”, cum a apreciat-o Nicolae Iorga, va fi fost pecetluită prin victoria, care a uimit Europa, a aceluiaşi Basarab I, de la Posada (912 noiembrie 1330), împotriva uneia dintre cele mai puternice şi orgolioase armate ale acelei epoci, cea a Regatului Ungar, comandată directă de regele Carol Robert de Anjou.

Impunânu-se ca stat afirmat şi consolidat, Ţara Românească va fi început să conteze în jocurile diplomatice, voievozii/domnitorii, în funcţie de împrejurări, încheind căsătorii conjuncturale şi dinastice, tratate de alianţă sau de închinare (suzeranitate), asigurând astfel statalitatea, dar şi suveranitatea, căci, a fi fost în stare de suzeranitate nu însemna pierderea totală a neatârnării şi a ţării.

Primejdiile pentru Ţara Românească nu au trecut însă, Regatul Ungar nerenunţând la a-şi exercita dominaţia până la Dunărea de Jos şi Marea Neagră. Fiul lui Basarab I, Nicolae Alexandru (1352-1364), opunându-se ferm acestei „direcţii de atac” a Regatului Ungar, îşi ia titlul de domn autocrat, şi revigorează Mitropolia Ţării Româneşti, înfiinţată de tatăl său, Basarab I, dependentă de patriarhul ecumenic de la Costantinopol. Gestul de autoritate şi de independenţă al domnitorului/voievodului ,însemna respingerea efortului regalităţii ungare de a impune Ţării Româneşti catolicismul”, ţara fiind astfel înzestrată ,cu instituţiile supreme ale statului de sine stătător". [2]
Pentru domn/voievod, revigorarea Mitropoliei, recunoscută de patriarhul Calist I al Constantinopolului în luna mai a anului 1359, întâiul mitropolit, atestat documentar, Iachint de la Vicina, ipso facto devenind şi sfetnicul principal al conducătorului statului şi „exarh a toată Ungrovlahia şi al plaiurilor" - acest statut avându-l toţi mitropoliţii care au urmat -, ca atare păstorindu-i şi pe românii plaiurilor, deci, de peste munte, din teritoriile adjudecate cu titlul de feudă, i-a îngăduit domnului/voievodului, considerându-se ,acoperit” de puterea Imperiului Bizantin, să acţioneze în relaţiile internaţionale cu mai multă libertate, temeritate şi demnitate în beneficiul Ţării Româneşti. Prin jocul abil diplomatic, cât şi prin replicile militare date Regatului Ungar, domnii/voievozii au reuşit să dobândească de la acest regat, Severinul (Nicolae Alexandru la 1355), dar şi ,„ţara Făgăraşului” şi ,„ţara Amlaşului”, beneficiar fiind în 1366 Vladislav I/Vlaicu Vodă (1364-1377). De altminteri, nu erau altceva decât redobândiri din proprietatea strămoşească dacică.

2.

Venind în 1386 la domnia Țării Româneşti, strănepotul Întemeietorului Basarab I, Mircea I Basarab va fi avut de păstrat şi de consolidat, la rându-i, o mare moştenire statală încă, aşa cum am mai spus, la începuturile sale. Şi pentru a o păstra şi consolida, chiar de la debutul domniei sale, conştient că, altminteri, s-ar fi năruit întreaga construcţie, ,prima libertate românească”, Mircea va fi fost obligat să facă în aşa fel încât să nu apună steaua ,unei neatârnări recunoscută şi garantată de regatul vecin al Poloniei, de Ungaria..."[3]

Dar, ca un bun gspodar, Mircea se va fi gândit şi străduit să asigure o sustenabilă dezvoltare a ţării: economică: prin încurajarea mineritului, meşteşugurilor, comerţului, oferind înlesniri vamale mai ales pentru neguţătorii braşoveni şi lioveni; baterea de monedă proprie; militară: o eficientă 
organizare a forţei de luptă (oastea cea mare, oastea cea mică/permanentă după modelul occidental european), construcţia de cetăţi de apărare, şi în interiorul ţării, şi de-a lungul Dunării; politică: crearea unui sistem de alianţe vizând stăvilirea taifunului otoman şi creşterea, astfel, a prestigiului internaţional al țării. Asemenea predecesorilor săi, Mircea şi-a făcut făcut din Biserică un sprijinitor de nădejde, cei doi mitropoliţi din timpul domniei sale, Antim şi Atanasie al Severinului fiindu-i ,sfetnici de taină”, cel deal doilea refuzând să se supună patriarhului ecumenic Matei I. Amândoi 1-au încurajat pe Mircea în opera sa ctitoritoare de lăcaşuri ecleziale (terminarea bisericii mari a Mănăstirii Cozia, zidirea bisericii Mănăstirii Snagov, posibil construirea primei biserici a Mănăstirii Dealu sau mănăstirile Glavacioc, Vişina/Jiu). Această operă - este bine a recunoaşte - a avut şi aportul substanţial reorganizator şi cultural al Sfântului Nicodim de la Tismana (călugăr sârb), posibil înrudit cu Basarabii.

Mircea I a înţeles că o ţară, cu deosebire în vremurile sale, rezistă nu numai printr-o înţeleaptă şi eficientă orânduială internă, dar şi prin întărirea/apărarea teritoriului şi extinderea acestuia în acele zone vecine locuite majoritar de consângeni şi care, imanenţial, făceau parte din Vatra ancestrală etnoistorică. Şi care ar fi ţinut cât mai departe de centrul conducător al statului pericolul unor invazii lansate de inamici animaţi de apetituri acaparatoare de pământuri ale românilor. Aşa cum, în acea epocă, se avântau în asemenea aventuri Regatul Ungar şi Imperiul Otoman. În consecinţă, Mircea I va fi practicat, într-o acţiune de geniu militar, o politică tactico-strategică capabilă să-i consolideze domnia prin consolidarea teritoriului Ţării Româneşti într-o viziune de sorginte bizantină. Căci, Mircea a nutrit convingerea că ar fi avut de îndeplinit o misiune, aceea de continuator al tradiţiei Bizanţului imperial la nordul Dunării, de unde şi prezenţa heraldică a vulturului bicefal bizantin cusut pe cnemidele domitorului/ voiedvodului, aşa cum se pot vedea în tabloul votiv de la Mănăstirea Cozia şi în fresca de la Mănăstirea Curtea de Argeş.

Urmărindu-şi scopul de întărire a domniei, Mircea I va fi adus la ţară, în 1389, după o campanie declanşată la sfârşitul anului precedent, Dobrogea (,Terrarum Dobroticii”), înfrângând oastea otomană de sub comanda marelui vizir Ali-paşa. Astfel că Țara Româească va fi atins maxima sa extindere teritorială, asigurându-şi o importantă faţadă maritimă. În cosecinţă, cu îndreptăţire, Mircea I - sunt unii istorici care contestă această îndreptăţire, acuzându-1 pe marele voievod de infatuată exagerare, dar realitatea istorică îi cotrazice - se va fi intitulat frecvent, între 1389 şi 1417, invariabil aproape, în diferite acte de domnie, astfel: „Eu cel întru Hristos Dumnezeu bine credinciosul şi bine cinstitorul şi de Hristos iubitorul şi singurul stăpânitorul Io Mircea, mare voievod şi domn cu mila lui Dumnezeu stăpânind şi domnind toată ţara Ungrovlahiei şi părţile de peste munţi, încă şi spre părţile tătăreşti, şi Amlaşului şi Făgăraşului herţeg şi Banatului de Severin domn şi de amândouă părţile de peste toată Dunărea şi până la Marea cea mare şi cetăţii Dârstorului stăpânitor”. [4]

Strălucit titlu de domnie, nu? Mai impresionant chiar decât cel al lui Mihai Viteazul. Şi care este, dealtfel, imaginea geografică-politică pe care ne-o proiectează acest titlul? Aceea a unei prime Uniri medievale româneşti, recuperatoare, sub coroana unui inubliabil erou de epopee, a unor pământuri din Vatra ancestrală a neamului. Este un indubitabil ADEVĂR ISTORIC.

Să luăm pe rând decriptarea acestui strălucit titlu domnesc voievodal.

1. „Mare voievod şi domn (...) stăpânind şi domnind toată țara Ungrovlahiei”, adică Țara Românească de la Severin (culoarul Cerna-Timiş), în vest, la Milcov şi Siretul inferior, în est, şi de la Carpaţii Meridionali, în nord, şi Dunăre, în sud, cuprinzând între 
fruntariile sale provinciile istorice Muntenia şi Oltenia, ceea ce documente de cancelarie occidental europeană şi ale Papalităţii numesc Valahia Magna. Este vorba, deci, de baza teritorial statală stabilă, zestrea fundamentală voievo-dală transmisă de la Întemeietorul Basarab I la urmaşii de sânge, sau, în accepţiune geopolitică, un mittelpunkt în jurul căruia s-a arhitecturizat $\mathrm{o}$ ţară, forţa constructoare folosită cu succes de domni si voievozi fiind etno-energetismul românesc.

2. „Amlaşului şi Făgăraşului herţeg”. Aşadar, „părţile de peste munţi”, acele teritorii transilvane (ducate) primite ca feude de Vladislav I/ Vlaicu Vodă (1364-1377) de la Ludovic I de Anjou în 1366, drept „despăgubire” ca urmare a suzeranităţii acceptate de voievodul român. Însă, Radu I (1377-1383), le va fi pierdut în urma unui atac eşuat în iunie 1377, împotriva aceluiaşi Ludovic I de Anjou, cronica fraţilor italieni Gatari consemnând că, totuşi, regele Ungariei se simţise într-o mare primejdie. Apoi, Dan I (1377-1383), fratele vitreg al lui Mircea I, încercând să le recupereze nu va fi reuşit s-o facă. O va fi făcut el, Mircea I, în 1389 fără să tragă nicio săgeată peste Carpaţi, negociind abil cu Sigismund de Luxemburg, regele Regatului Ungar, acesta lăsându-se speriat de voievodul român cu spectrul real, de altminteri, al invaziei otomane, oferindu-i, în schimbul recuperării Amlaşului şi Făgăraşului, alianţa. Astfel că, la 1392 se intitula, „stăpân veşnic al Făgăraşului”.

3. „...încă şi spre părţile tătăreşti” (întrun alt titlu de domnii anteriori, ,peste părţile tătăreşti”) se referă la o moştenire de la domnii de dinainte, situată în sudul Moldovei de la Prutul inferior până la limanul Nistrului (Buceag). Cercetătorii istorici au însă şi astăzi unele dubii. Nu pun la îndoială că Mircea I nu ar fi stăpânit în acea parte de zare românească, doar că moştenirea ar fi greu de delimitat datorită lipsei de informaţii sigure. Sau că ar fi intrat în stăpânirea acelui spaţiu, care va fi cunoscut şi cu toponimul Basarabia, acesta trăgându-i-se de la dinastia
Basarabilor, partajându-1 şi trasându-i graniţele la învoială fie cu cumnatul său Roman I, părându-se ,că ambii domni se înţeleseseră pentru ca unul să ia Buceagul, iar celălalt să înainteze pe Nistru spre Cetatea Albă" [5], Mircea ajungând până la limanul nistrean, fie cu nepotul său, Alexandru cel Bun.

(N.B. De unde deumirea, ,părţile tătărești’’ Sintagma este consemnată astfel de cronici şi în acte de cancelarie domnească, şi vine de la marea invazie a triburilor mongole din secolul XIII, triburi care, unele dintre acestea, au campat câteva secole în sudul Moldovei istorice, cunoscute fiind ca „tătăreşti” după ,,altoirea” cu cumanii albi, de neam turcic. Până în secolul XV au făcut parte din marele stat mongol Hoarda de Aur, când acesta va fi înfrânt, destrămându-se.

„Buceag” în limba tătarilor = peninsulă, datorită formei de triunghi a ţinutului ocupat de aceştia în sudul Moldovei între Prutul inferior, Nistrul inferior, Dunărea maritimă şi codrii Tigheiului; colţ de pământ populat de colibe.)

4. „... şi Banatului de Severin, domn”, este, de asemenea, o moştenire de la Basarabii de dinaintea-i, lui Mircea recunoscându-i-se stăpânirea de către regalitatea maghiară în 1393, aceasta având evident nevoie de ajutorul voievodului valah, presiunea otomană fiind în creştere la Dunăre în urma prăbuşirii ţaratului bulgar de la Tîrnovo devenit paşalâc.

5. „... şi de amândouă părţile peste toată Dunărea şi până la Marea cea Mare şi cetăţii Dârstorului stăpânitor”. Pământul dintre Dunăre şi Marea Neagră, Dobrogea, va fi unit cu ţara, cum am arătat mai înainte, prin cucerirea sa de la ocupantul otoman în 1389, îl pierde în 1394, după căderea ţaratului de la Târnovo, recucerindu-1 în 1404, când va fi adjudecată şi Silistra (Dârstorul) prin luptă, tot de la otomani, pe care îi va înfrânge la 14071408 în faţa aceleeaşi cetăţi care, pentru Ţara Românească va fi avut o dublă însemnătate: strategică, de avanpost la ameninţările Semilunii, şi de cale comercială lesnicioasă 
spre porturile de la Marea Neagră. Mai există şi ipoteza conform căreia Dobrogea şi Silistra le-ar fi moştenit de la tatăl său Radu I [6], părere care nu are un suport documentar, mai degrabă ar fi să dăm crezare altor istorici, care emit probabilitatea ca teritoriul fostei Scythia Minor să fi ajuns în posesia lui Mircea, datorită ajutorului acordat despotului Ivanco, fiul lui Dobrotici, atacat de turcii otomani. (Constantin C. Giurescu; Dinu C. Giurescu, ,Istoria românilor”, Ed. Albatros, Bucureşti, 1971, p. 282).

Odată cu mărirea teritoriului Țării Româneşti până la Marea Neagră (Marea cea Mare) s-a ivit necesitatea, pe care Mircea I a înţeles-o bine, ca guvernarea statului, care reclama o multitudine de responsabilităţi, urmare a extinderii, să fie distribuită în doi, ca atare, 1-a asociat la domnie (coregenţă) pe unul dintre fii săi, este vorba de Mihail, stabilindu-i reşedinţă la Târgovişte. Astfel că cetatea de pe Ialomiţa capătă rang de capitală către finele secolului XIV - astăzi se ştie că voievodul a ales-o din raţiuni strategice, cealaltă capitală de la Curtea de Argeş intrând în declin -, şi nu una oarecare, ci unionistă. Ca să fim corecţi, acest status îl împarte o vreme cu Curtea de Argeş, apoi rămâne singura capitală, se pare, în ultimii ani ai domniei lui
Mircea I, ai primului Întregitor, deci, al unor pământuri româneşti.

Acum, la sfârşitul acestui demers, putem spune reiterator cu certitudine: sub sceptrul creştin al lui Mircea I Basarab s-a înfăptuit prima Unire românească medievală. Fie-i eternă aducerea aminte şi bine meritata cinstire în sufletul şi conştiinţa neamului românesc!

\section{Referinţe}

[1] Nicolae Iorga, „Istoria românilor. Ctitorii", vol III, Ed. Enciclopedică, Bucureşti, 1993, pp. 135; 136

[2] Şerban Papacostea, „De la geneza statelor româneşti la naţiunea română", în „Istoria României”, Ed. Enciclopedică, Bucureşti, 1999, p. 156

[3] Nicolae Iorga, op. cit, p. 221

[4] Giurescu, Constantin C.; Giurescu, Dinu C.; „Istoria românilor din cele mai vechi timpuri şi până astăzi”, Ed. Albatros, Bucureşti, 1971, p. 281.

[5] N. Iorga, op.cit. p. 242.

[6] A.D. Xenopol, „Istoria românilor din Dacia Traiană”, vol II, Ed. Ştiinţifică şi Enciclopedică, Bucureşti, 1986, p.79.

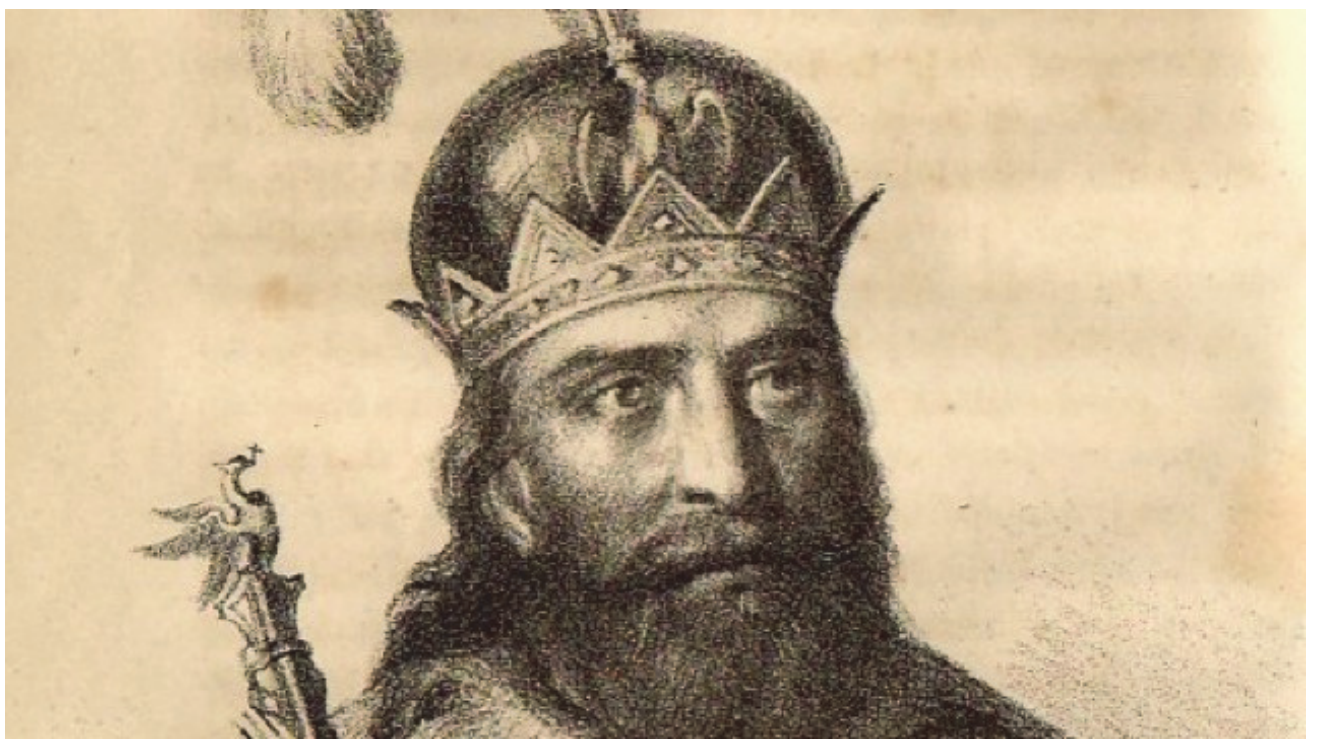

